\title{
EVALUATION OF FORAGE YIELD AND SILAGE QUALITY OF SWEET SORGHUM IN THE EASTERN MEDITERRANEAN REGION
}

\author{
C. Yucel ${ }^{1 *}$ and M. E. Erkan² \\ Dept. of Field Crops, Faculty of Agriculture, University of Sirnak, Turkey \\ Dept. of Food Hygiene and Technology, Faculty of Veterinary Medicine, University of Dicle, Diyarbakır, Turkey \\ ${ }^{*}$ Corresponding author's E-mail address: celalyucel1@gmail.com
}

\begin{abstract}
Different sweet sorghum varieties were ensiled and silage quality attributes were determined in the present study. M81-E, Ramada, Roma, Topper-76, UNL Hybrid and No91 sweet sorghum (Sorghum bicolor var. saccharatum (L.) Mohlenbr.) genotypes were used as the plant material for the study. Field experiments were conducted at the experimental fields of Eastern Mediterranean Agricultural Research Institute (Dogankent-Adana) in the years 2016 and 2017 under second-crop conditions (June-October) in a randomized complete block design with four replications. Average green herbage yield, dry matter yield, crude protein yield, crude protein (CP) ratio, neutral detergent fiber (NDF), acid detergent fiber (ADF), dry matter intake (DMI) and relative feed value (RFV) varied between 151.5-188.7 $\mathrm{Mg} \mathrm{ha}^{-1} ; 46.6-61.2 \mathrm{Mg} \mathrm{ha}^{-1} ; 2166-2905 \mathrm{~kg}$ $\mathrm{ha}^{-1} ; 4.08-5.22 \%, 39.11-43.10 \%, 24.31-28.36 \%, 2.81-3.11 \%$, and 148.3-168.4. Present findings revealed that M81-E, Topper-76, UNL hybrid and No91 varieties were higher with herbage and DM yield while Ramada and Roma were higher with silage quality attributes. It was observed that the sweet sorghum varieties at second-crop growing period (JuneOctober) under Eastern Mediterranean (Adana) conditions for 100-120 days had green herbage, dry matter and crude protein yields more than $180 \mathrm{Mg} \mathrm{ha}^{-1}, 50 \mathrm{Mg} \mathrm{ha}^{-1}$ and $2300 \mathrm{~kg} \mathrm{ha}^{-1}$, respectively. These varieties had RFV of above 150. Such a value was greater than the RFV of several other forage crops.
\end{abstract}

Key words: Sweet sorghum; silage; cultivar; quality.

https://doi.org/10.36899/JAPS.2020.4.0108

Published online April 25, 2020

\section{INTRODUCTION}

Sweet sorghum has less fertilizer requirements and soil preference, more tolerant to salinity, droughts and high temperatures, and use irrigation water more efficiently, thus can reliably be grown over the agricultural fields of arid and semi-arid regions. Such attributes give sweet sorghum an advantage over the other fodder crops grown under similar conditions (Mastrorilli et al., 1999; Gnansounou et al., 2005; Tesso et al., 2005; Almodares et al., 2008). Sweet sorghum is a short-day plant, thus requires high temperatures and exhibit the best growth under high temperature conditions (Reise and Almodares, 2008).

Since sorghum plants have quite high soluble carbohydrate contents (Sankarapandian et al., 2013), high nutrient contents and low buffering capacities (Lema et al., 2001, Kumar et al., 2015), are commonly used for silage production (Brocke et al., 2014). Sweet sorghum silage has greater dry matter digestibility (DMD), thus provides a good quality feed source for ruminants. Sorghum varieties have greater potential for silage when they were grown as the second crop (Neto et al., 2017). Sweet sorghum stalks are quite rich in fermentable sugars (about $15-18 \%$ richer than regular sorghums) (Reddy et al., 2005). Such attributes facilitate lactic acid fermentation (Santos et al., 2013) and make it suitable crop for silage.
Mediterranean climate has hot and dry summers. Cool-season Gramineae species are dominant over the pastures of Mediterranean region and thus they usually get into dormant state in summers and have quite low yield and quality in this season. Therefore, alternative feed crops should be grown in this season. In this case, summer C4 plants with high unit-area yields like sorghum can be grown to meet quality roughage needs of livestock under Mediterranean conditions. Studies about potential use of sweet sorghum of Turkey as a quality forage source are quite limited.

In this study, different sweet sorghum varieties were grown under ecological conditions of Adana province as the summer second crop after wheat, plants were ensiled to determine forage potential and some quality attributes of sweet sorghums.

\section{MATERIALS AND METHODS}

Material: Sweet sorghum varieties M81-E, Ramada, Roma, Topper 76, UNL-hybrid (26297xM81E) were supplied by UNL (University of Nebraska, Lincoln, USA) and No91 population (Taiwan-originated and supplied from USDA gene bank) were used as the plant material of this study. 
Climate and soil characteristics of the experimental site; Average temperature between the months JuneOctober was $25.1^{\circ} \mathrm{C}$ in 2016 and $24.8^{\circ} \mathrm{C}$ in 2017 . Those values were similar with the long-term averages. Temperatures in June, July and August were around 42-43 ${ }^{\circ} \mathrm{C}$. Average relative humidity of the same period was $79.0 \%$ and total precipitation was $46-48 \mathrm{~kg} / \mathrm{m}^{2}$.

Experimental soils belong to Arikli soil series. Soil samples were taken from $0-15$ and $15-30 \mathrm{~cm}$ soil profiles. Analyses revealed that soil $\mathrm{pH}$ varied between 7.0 and 7.50 , total salt varied between 0.22 and $0.27 \%, \mathrm{~N}$ between 0.10 and $0.19 \%$, organic carbon (OC) between 0.63 and $0.90 \%$, phosphorus $(\mathrm{P})$ between 0.63 and $0.90 \mathrm{mg}$ $\mathrm{kg}^{-1}$, lime content $\left(\mathrm{CaCO}_{3}\right)$ between 32.5 and $35.0 \%$, sand between 24 and $28 \%$, silt between 41 and $43 \%$, clay between 30 and $33 \%$ and soil texture was clay-loam(CL).

Experimental Setup: Field experiments were conducted in 2016 and 2017 over the experimental fields of Dogankent Locality of Eastern Mediterranean Agricultural Research Institute (DATAEM) (36 $56^{\circ}$ ' $35^{\prime \prime} \mathrm{N}$ and $35^{\circ} 20^{\prime}$ $43^{\prime \prime}$ E) in a randomized complete block design with four replications. Sowing was performed after wheat harvest in mid-June. Before sowing, $50 \mathrm{~kg} \mathrm{ha}^{-1}$ of both nitrogen and phosphorus were applied to experimental plots as base fertilizer. Each variety was sown at $70 \mathrm{~cm}$ row spacing and $15 \mathrm{~cm}$ on-row plant spacing over $5 \mathrm{~m}$ long 4 rows. When the plants reached to a height of $40-50 \mathrm{~cm}$, additional $50 \mathrm{~kg}$ $\mathrm{ha}^{-1}$ pure nitrogen was supplied manually as top-dressing fertilizer and irrigations were initiated then. Plants were harvested at different dates between milk and dough stages. Side rows and $0.5 \mathrm{~m}$ sections from the top and bottom of the plots were omitted as to consider the side effects and manual harvest was performed from the remaining sections of middle two rows. Plot yields were determined and then yields per hectare were calculated accordingly.

Sample preparation and chemical analyses: For harvest, five plants were randomly selected from each plot and were used to make silage. The selected five plants (leaf-stalk and panicle) were chopped into $3-5 \mathrm{~cm}$ pieces with a chipperchopper machine and made ready for ensilage. About $1 \mathrm{~kg}$ fresh samples were placed into special plastic bags $(\geq 110 \mu$ thickness) in two parallels for each plot and oxygen was removed by $99.9 \%$ with the aid of Crompack vacuum device. Bags were automatically sealed to finalize ensilage. Vacuumed silage materials were preserved at room temperature for 60 days. Ensiled materials were dried, weighed and ground to pass through 1-2 mm sieves. Kjeldahl method was used to determine nitrogen $(\mathrm{N})$ content of the ground samples. Crude protein ratio was determined with the aid of equation of $\mathrm{Nx} 6.25$ (AOAC, 1990). Of the cell membrane components, ADF, ADL and NDF ratios (\%) of the samples were determined in accordance with the method specified by Van Soest et al. (1991) with an ANKOM fiber analyzer device. Digestible dry matter ratios (DDM), dry matter intake (DMI) and relative feed value (RFV) of the samples were determined by using the equations provided by Schroeder (1994): $\mathrm{DDM}=88.9-(0.779 \times \mathrm{ADF} \%)$; $\mathrm{DMI}=120 / \mathrm{NDF} \%$; RFV= (DDM\% x DMI\%)/1.29. Net Energy (NE) (Mcal/kg) was calculated by using the equation of $\mathrm{NE}=1.892$ (0.0141*ADF) (Anonymous, 2018).

Experimental data were analyzed using proc mixed procedure in SAS program in accordance with randomized complete blocks design (RCBD). Significant means were compared using TUKEY test at 5\% level (Littell et al., 2006).

\section{RESULTS AND DISCUSSION}

Biomass Yield ( $\left.\mathrm{Mg} \mathrm{ha}^{-1}\right)$ : For biomass yield, also called as fresh biomass or green herbage yield, the varieties and varieties $\mathrm{x}$ year interactions were found to be significant. Biomass yields of the years and varieties varied between 129.5 and 206.7 $\mathrm{Mg} \mathrm{ha}^{-1}$. M81-E, Topper-76, UNL hybrid and No91 varieties had biomass yields of over $180 \mathrm{Mg} \mathrm{ha}^{-1}$. In previous studies conducted with different genotypes under different ecologies, biomass yields were reported as between 11.5 and $112 \mathrm{Mg} \mathrm{ha}^{-1}$ (Turgut et al., 2005; Korpos et al., 2008; Bellmer et al., 2010; Agung et al., 2013; Perazzo et al., 2017). Present biomass yields were greater than those earlier ones and such greater values indicated that present ecology was suitable for sorghum culture.

Dry Matter Yield $\left(\mathrm{Mg} \mathrm{ha}^{-1}\right)$ : For dry matter yield, means of year and varieties and variety $\mathrm{x}$ year interactions were found to be significant. Dry matter yields of the years and varieties varied between 38.8 and $69.0 \mathrm{Mg} \mathrm{ha}^{-1}$. As the average of years, the greatest dry matter yield was obtained from UNL hybrid genotype. In earlier studies conducted with different genotypes at different ecologies, dry matter yields were reported as between 6.59 and $33.9 \mathrm{Mg} \mathrm{ha}^{-1}$ (Turgut et al., 2005; Bellmer et al., 2010; Perazzo et al., 2017; Ekefre et al., 2017). As it was in biomass yields, present dry matter yields were also greater than the earlier ones. Significant positive correlations were reported between herbage yield and dry matter yield (Iyanar et al., 2010).

pH: Effects of years, varieties and variety $\mathrm{x}$ year interactions on silage $\mathrm{pH}$ values were found to be significant (Table 2). The $\mathrm{pH}$ values of the years and varieties varied between 3.21 and 3.82. Feed sorghum silage is fermented like as maize silage and generally has a pH of below 4 (Filya, 2003; Contreras-Govea et al., 2010). Junior et al. (2015) reported $\mathrm{pH}$ of sorghum silage as between 3.60 and 3.68. Present findings comply with those earlier reports.

Crude Protein Ratio (\%): There were significant differences in crude protein ratios of the varieties and years. Crude protein ratios of the varieties varied between 4.08 and $5.22 \%$ and Ramada variety had greater $\mathrm{CP}$ ratios than 
the others. In previous studies, crude protein ratios of sweet sorghum varieties were reported as between 2.6-8.23\% (Lema et al., 2001; Madibela et al., 2002; Rodrigues et al., 2006; Junior et al., 2015; Durul, 2016). Present findings were within the earlier reports, greater than some and smaller than the others. Such differences were attributed to differences in varieties, ecologies and growing techniques.

Table 1. Biomass and dry matter yields of sweet sorghum varieties.

\begin{tabular}{lcccccc}
\hline Cultivars & \multicolumn{3}{c}{${\text { Biomass Yield }\left(\mathbf{M g ~ h a}^{-1}\right)}^{-}$} & \multicolumn{3}{c}{ Dry Matter Yield $\left(\mathbf{M g ~ h a}^{-\mathbf{1}}\right)$} \\
\cline { 2 - 7 } & $\mathbf{2 0 1 6}$ & $\mathbf{2 0 1 7}$ & Mean & $\mathbf{2 0 1 6}$ & $\mathbf{2 0 1 7}$ & Mean \\
\hline M81-E & $181.0 \mathrm{ab}$ & $179.2 \mathrm{ab} \mathrm{b}^{1}$ & $180.1 \mathrm{AB}^{*}$ & $56.6 \mathrm{abc}$ & $51.1 \mathrm{bcd}$ & $53.8 \mathrm{AB}^{*}$ \\
Ramada & $129.5 \mathrm{~b}$ & $173.4 \mathrm{ab}$ & $151.5 \mathrm{~B}$ & $43.0 \mathrm{ecd}$ & $50.2 \mathrm{bcd}$ & $46.6 \mathrm{~B}$ \\
Roma & $157.1 \mathrm{ab}$ & $182.3 \mathrm{ab}$ & $169.7 \mathrm{AB}$ & $51.8 \mathrm{bcd}$ & $46.1 \mathrm{~cd}$ & $48.9 \mathrm{~B}$ \\
Topper 76 & $177.7 \mathrm{ab}$ & $185.4 \mathrm{a}$ & $181.5 \mathrm{AB}$ & $53.6 \mathrm{a}-\mathrm{d}$ & $47.8 \mathrm{~cd}$ & $50.7 \mathrm{~B}$ \\
UNLHybrid & $193.8 \mathrm{a}$ & $183.6 \mathrm{ab}$ & $188.7 \mathrm{~A}$ & $69.0 \mathrm{a}$ & $53.4 \mathrm{a}-\mathrm{d}$ & $61.2 \mathrm{~A}$ \\
No91 & $206.7 \mathrm{a}$ & $170.5 \mathrm{ab}$ & $188.6 \mathrm{~A}$ & $65.9 \mathrm{ab}$ & $38.8 \mathrm{~d}$ & $52.3 \mathrm{AB}$ \\
Mean & 174.3 & 179.1 & 176.7 & $56.7 \mathrm{~A}^{+}$ & $47.9 \mathrm{~B}$ & 52.3 \\
CV $(\%)$ & & 12.39 & & & 12.91 & \\
\hline
\end{tabular}

$\left.{ }^{*}\right)$ The means indicated with the same capital letter in the same column are not significantly different according to the Tukey test at $\mathrm{P} \leq 0.05$

+ ) The means indicated with the same capital letter in the same row are not significantly different according to the Tukey test at $\mathrm{P} \leq 0.05$

1) The means of different year-cultivar combinations with the same lower case letters are not significantly different according to the Tukey test at $\mathrm{P} \leq 0.05$

Table 2. Silage pH and crude protein ratios of sweet sorghum varieties.

\begin{tabular}{lcccccc}
\hline Cultivars & \multicolumn{1}{c}{$\mathbf{p H}$} & & \multicolumn{3}{c}{ Crude Protein Ratio (\%) } \\
\cline { 2 - 7 } & $\mathbf{2 0 1 6}$ & $\mathbf{2 0 1 7}$ & Mean & $\mathbf{2 0 1 6}$ & $\mathbf{2 0 1 7}$ & Mean \\
\hline M81-E & $3.42 \mathrm{bc}$ & $3.40 \mathrm{bc}^{1}$ & $\mathbf{3 . 4 1} \mathbf{A B}^{*}$ & 3.54 & 4.80 & $\mathbf{4 . 0 8 ~}^{*}$ \\
Ramada & $3.46 \mathrm{bc}$ & $3.59 \mathrm{ab}$ & $\mathbf{3 . 5 2} \mathbf{A}$ & 4.97 & 5.47 & $\mathbf{5 . 2 2} \mathbf{A}$ \\
Roma & $3.36 \mathrm{bc}$ & $3.82 \mathrm{a}$ & $\mathbf{3 . 5 9} \mathbf{A}$ & 4.46 & 4.99 & $\mathbf{4 . 7 2} \mathbf{A B}$ \\
Topper 76 & $3.43 \mathrm{bc}$ & $3.53 \mathrm{abc}$ & $\mathbf{3 . 4 8} \mathbf{A B}$ & 4.10 & 5.15 & $\mathbf{4 . 6 2} \mathbf{A B}$ \\
UNLHybrid & $3.53 \mathrm{abc}$ & $3.54 \mathrm{abc}$ & $\mathbf{3 . 5 3} \mathbf{A}$ & 4.54 & 5.05 & $\mathbf{4 . 7 9} \mathbf{A B}$ \\
No91 & $3.37 \mathrm{bc}$ & $3.21 \mathrm{c}$ & $\mathbf{3 . 2 9} \mathbf{B}$ & 3.48 & 5.40 & $\mathbf{4 . 4 4} \mathbf{A B}$ \\
Mean & $\mathbf{3 . 4 3} \mathbf{B}$ & $\mathbf{3 . 5 1} \mathbf{A}^{+}$ & $\mathbf{3 . 4 7}$ & $\mathbf{4 . 1 5} \mathbf{B}$ & $\mathbf{5 . 1 4} \mathbf{A}$ & $\mathbf{4 . 6 5}$ \\
CV $(\mathbf{\%})$ & & $\mathbf{4 . 0 5}$ & & & $\mathbf{1 2 . 7 0}$ & \\
\hline
\end{tabular}

$\left.{ }^{*}\right)$ The means indicated with the same capital letter in the same column are not significantly different according to the Tukey test at $\mathrm{P} \leq 0.05$

+ ) The means indicated with the same capital letter in the same row are not significantly different according to the Tukey test at $\mathrm{P} \leq 0.05$

1) The means of different year-cultivar combinations with the same lower case letters are not significantly different according to the Tukey test at $\mathrm{P} \leq 0.05$

Crude Ash Content (\%): Significant differences were observed in crude ash contents only of the years. Crude ash (CA) contents of the years and varieties varied between 4.87 and $7.48 \%$. Average ash content of the first year $(6.73 \%)$ was greater than the ash content of the second year $(5.83 \%)$. Dry matter ratios were also greater in the first year than in the second year (Figure 1). Such a case may be related to leaf-stalk ratio. Madibela et al. (2002) reported greater CA content for leaves (115 g kg DM) than for stalks (60.2 g kg DM) of sweet sorghum. Similarly, Elseed et al. (2007) indicated that plant stalks tend to have less ash and silica; Monti et al. (2008) reported greater ash content for leaves ( $82 \mathrm{~g} \mathrm{~kg} \mathrm{DM})$ than for stalks (50 $\mathrm{g} \mathrm{kg} \mathrm{DM})$ of sweet sorghums. Crude ash contents of sorghum were reported as between 2.5 and 4.9\% (Lema et al., 2001; Trulea et al., 2013). Madibela et al. (2002) reported crude ash contents of sweet sorghum varieties as between 69.4 and $91.5 \mathrm{~g} \mathrm{~kg}$ DM.

Acid Detergent Lignin (\%): The differences in acid detergent lignin (ADL) values of the varieties were not found to be significant (Table 3). ADL values of the years and varieties varied between 4.36 and $6.90 \%$. In previous studies, ADL values of sweet sorghum varieties were reported as between 3.5 and 5.2\% (Lema et al., 2001) and between 25.5 and $39.8 \mathrm{~g} \mathrm{~kg} \mathrm{DM} \mathrm{(Madibela} \mathrm{et} \mathrm{al.,} \mathrm{2002).}$

Neutral Detergent Fiber (\%): Only the years were found to be significant for neutral detergent fiber (NDF). The NDF values of the years and varieties varied between 35.15 and $46.90 \%$. The varieties Ramada and Roma had lower NDF values than the others. Such a case was attributed to greater leaf ratios of these varieties. Similar findings were also reported by Yucel et al. (2018). NDF value of the first 
year (43.96\%) was greater than the second year (38.54\%). Such a case was attributed to greater DM yield of the first year (Table 1), thus to greater ripening of the plants and increased cell membrane substances. In previous studies, NDF values of sweet sorghum varieties were reported as between 32.6 and 64.9\% (Lema et al., 2001; Gomes et al., 2006; Mahmood et al., 2013; Durul, 2016; Neto et al., 2017). Present findings comply with those earlier ones.

Acid Detergent Fiber (\%): The differences in acid detergent fiber (ADF) values of the varieties were found to be significant. ADF values of the years and varieties varied between 23.62 and $29.18 \%$. As it was in NDF values, again the varieties Ramada and Roma had lower ADF values. Such a case was attributed to leafy nature of the stalks. In general, ADF, ADL and cellulose contents followed the same trend as NDF (Lema et al., 2001). In previous studies, $\mathrm{ADF}$ values of sweet sorghum varieties were reported as between 24.4 and 42.0\% (Lema et al., 2001; Mahmood et al., 2013; Durul, 2016) and between 260.0-324.4 g kg DM (Madibela et al., 2002).

Table 3. Silage crude ash and ADL values of sweet sorghum varieties.

\begin{tabular}{|c|c|c|c|c|c|c|}
\hline \multirow[t]{2}{*}{ Cultivars } & \multicolumn{3}{|c|}{ Crude Ash Content (\%) } & \multicolumn{3}{|c|}{ Acid Detergent Lignin (\%) } \\
\hline & 2016 & 2017 & Mean & 2016 & 2017 & Mean \\
\hline M81-E & 7.06 & 4.87 & 5.97 & 6.90 & 5.71 & 6.30 \\
\hline Ramada & 6.25 & 5.75 & 5.99 & 5.13 & 5.06 & 5.09 \\
\hline Roma & 6.72 & 5.41 & 6.06 & 5.33 & 4.86 & 5.10 \\
\hline Topper 76 & 7.48 & 6.60 & 7.04 & 5.71 & 4.36 & 5.04 \\
\hline UNLHybrid & 7.32 & 5.54 & 6.43 & 6.05 & 6.25 & 6.15 \\
\hline No91 & 5.58 & 6.79 & 6.19 & 5.75 & 5.69 & 5.72 \\
\hline Mean & $6.73 \mathrm{~A}$ & $5.83 \mathrm{~B}^{+}$ & 6.28 & 5.81 & 5.32 & 5.57 \\
\hline CV (\%) & & 18.49 & & & 19.54 & \\
\hline
\end{tabular}

+) The means indicated with the same capital letter in the same row are not significantly different according to the Tukey test at $\mathrm{P} \leq 0.05$

Table 4. Silage NDF and ADF values of sweet sorghum varieties.

\begin{tabular}{lcccccc}
\hline Cultivars & \multicolumn{3}{c}{ Neutral Detergent Fiber (\%) } & \multicolumn{3}{c}{ Acid Detergent Fiber (\%) } \\
\cline { 2 - 7 } & 2016 & 2017 & Mean & 2016 & 2017 & Mean \\
\hline M81-E & 46.90 & 39.31 & $\mathbf{4 3 . 1 0}$ & 29.18 & 27.54 & $\mathbf{2 8 . 3 6} \mathbf{A}^{*}$ \\
Ramada & 43.07 & 35.15 & $\mathbf{3 9 . 1 1}$ & 25.00 & 23.62 & $\mathbf{2 4 . 3 1} \mathbf{B}$ \\
Roma & 42.93 & 35.62 & $\mathbf{3 9 . 2 8}$ & 26.56 & 23.94 & $\mathbf{2 5 . 2 5}$ AB \\
Topper 76 & 44.29 & 39.53 & $\mathbf{4 1 . 9 1}$ & 26.13 & 26.56 & $\mathbf{2 6 . 3 5} \mathbf{A B}$ \\
UNLHybrid & 42.55 & 39.57 & $\mathbf{4 1 . 0 6}$ & 28.31 & 28.04 & $\mathbf{2 8 . 1 7} \mathbf{A B}$ \\
No91 & 44.05 & 42.04 & $\mathbf{4 3 . 0 5}$ & 26.70 & 29.13 & $\mathbf{2 7 . 9 1 ~ A B}$ \\
Mean & $\mathbf{4 3 . 9 6} \mathbf{A}$ & $\mathbf{3 8 . 5 4} \mathbf{B}^{+}$ & $\mathbf{4 1 . 2 5}$ & $\mathbf{2 6 . 9 8}$ & $\mathbf{2 6 . 4 7}$ & $\mathbf{2 6 . 7 3}$ \\
CV $(\%)$ & & 7.81 & & & 10.01 & \\
\hline
\end{tabular}

$\left.{ }^{*}\right)$ The means with the same capital letter in the same column are not statistically significant different from each other according to the Tukey test at $\mathrm{P} \leq 0.05$

+ ) The means with the same capital letter in the same row are not statistically significant different from each other according to the Tukey test at $\mathrm{P} \leq 0.05$

Dry Matter Ratio (\%): For silage dry matter (DM) ratios, varieties, years and variety $\mathrm{x}$ year interactions were found to be significant. DM ratios of the years and varieties varied between 24.75 and $38.94 \%$. The DM ratios of the varieties alone varied between 29.68 and $35.34 \%$ with the greatest value in UNL hybrid genotype (Figure 1). DM ratio of the first year $(35.59 \%)$ was greater than the second year (29.33\%). Chakravarthi et al. (2017) reported DM ratios of sweet sorghum varieties as between 11.82 and $38.19 \%$ with an average value of $26.30 \%$.
Digestible Dry Matter Ratio (\%): Significant differences were not observed in digestible dry matter (DDM) ratios of the years and the varieties. DDM ratios of the years and varieties varied between 67.15 and $72.18 \%$ (Figure 1). Increasing stalk sugar content increase digestibility and feed quality (Poehlman, 1994; Blümmel et al., 2009). Digestible dry matter ratios of sorghum were reported as between 56.96 and 70.65\% (Junior et al., 2015; Karthikeyan et al., 2017). 


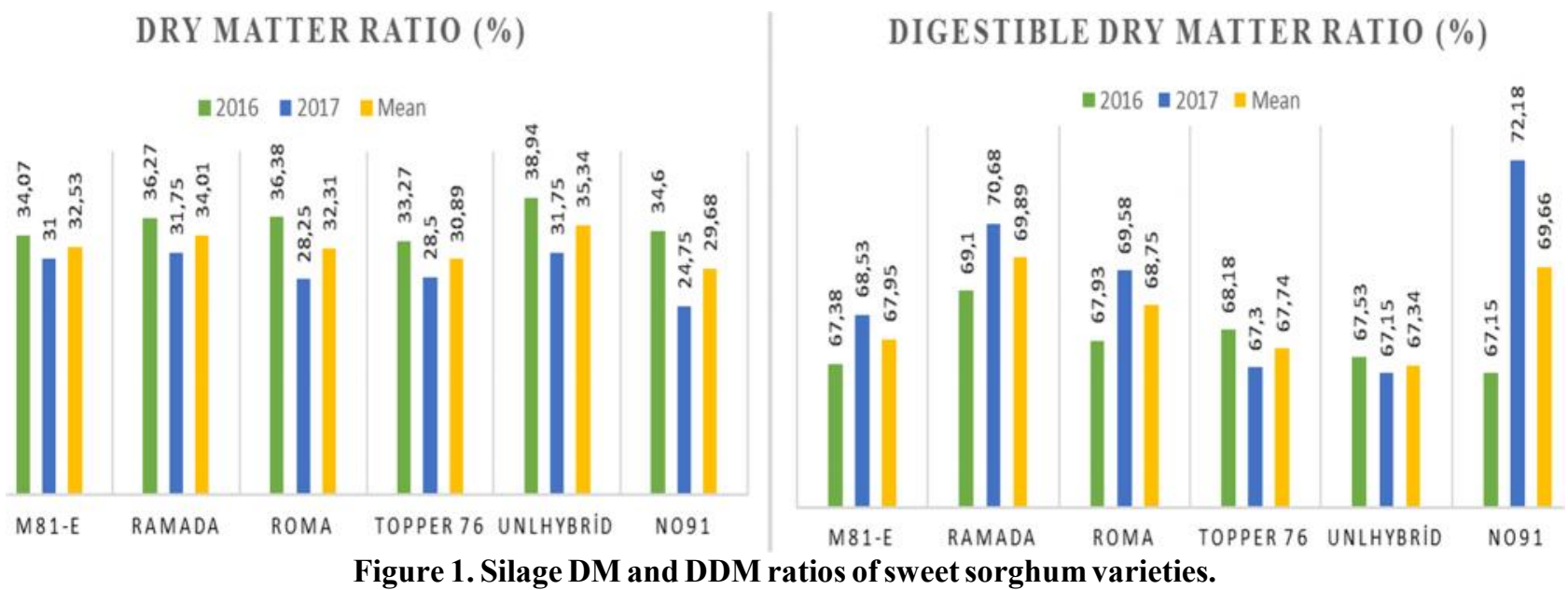

Dry Matter Intake (\%): Years and varieties were found to be significant for dry matter intake (DMI) values. DMI values of the years and varieties varied between 2.56 and $3.37 \%$ and DMI values of the varieties varied between 2.81 and $3.11 \%$ (Figure 2). The varieties Ramada and Rome had greater DMI values $(>3 \%)$ than the others. Average DMI value of the second year $(3.15 \%)$ was greater than the DMI value of the first year (2.74\%). Karthikeyan et al. (2017) reported DMI values of sweet sorghum varieties as between 1.67 and $2.20 \%$ with an average value of $1.93 \%$. Silage fermentation quality had significant effects on feed intake, nutrient use and milk yield of ruminants (Huhtanen et al., 2002).
Relative Feed Value: For relative feed value (RFV), both the years and the varieties were found to be significant. RFV of the years and varieties varied between 133.9 and 187.1. RFV of the varieties varied between 148.3 and 168.4 (Figure 2). The varieties Ramada and Rome had greater RFV $(>165)$ than the others. Average RFV of the second year (168.9) was greater than the average RFV of the first year (144.1). The RFV value calculated based on $100 \%$ flowering period of alfalfa was assumed to be 100. Durul (2016) reported RFV of sweet sorghum varieties as between 104 and 126.
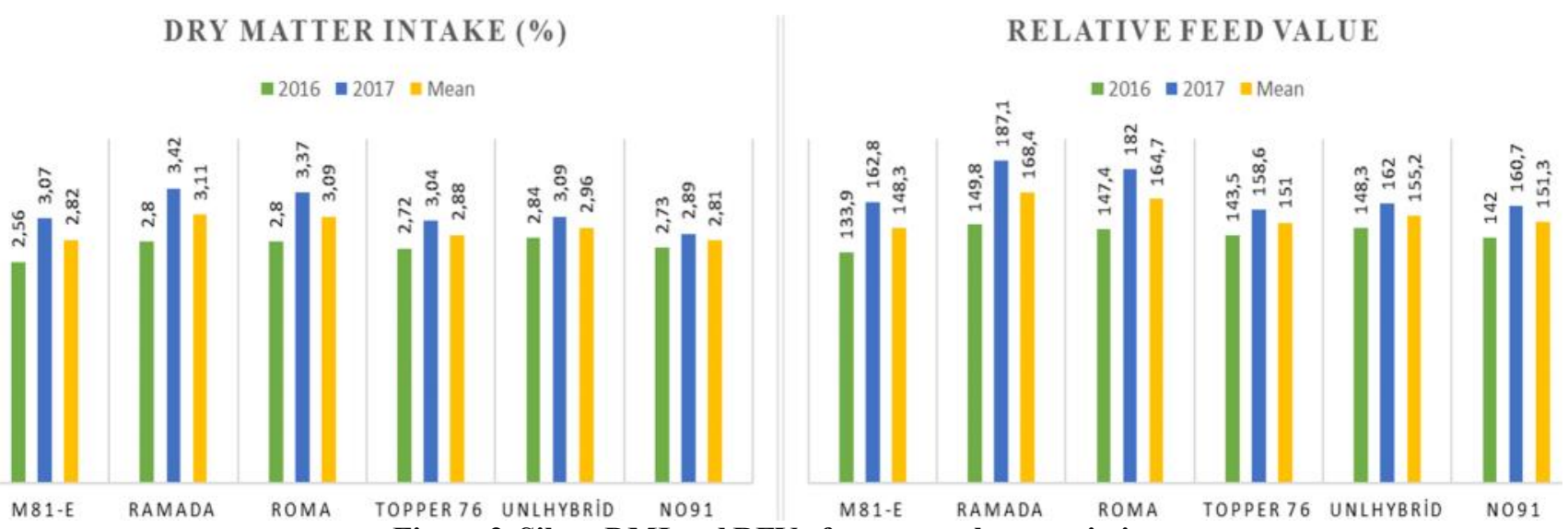

Figure 2. Silage DMI and RFV of sweet sorghum varieties

Crude Protein Yield $\left(\mathrm{kg} \mathrm{ha}^{-1}\right)$ : Variance analysis revealed that there were significant differences in silage crude protein $(\mathrm{CP})$ yields of the varieties. The $\mathrm{CP}$ yields of the years and varieties varied between 1900 and $3128 \mathrm{~kg} \mathrm{ha}^{-1}$ (Figure 3). The CP yields of the varieties varied between 2166 and $2905 \mathrm{~kg} \mathrm{ha}^{-1}$ with the greater value in UNL hybrid genotype than the others.

Net Energy (Mcal kg-1): Significant differences were not observed between the net energy values of the years and the varieties. Net energy values of the years and varieties varied between 1.498 and $1.590 \mathrm{Mcal} \mathrm{kg}^{-1}$ (Figure 3). High net energy values of sweet sorghum varieties are generally attributed to high water soluble carbohydrate content of sweet sorghum (Kaiser et al., 2004). Cattani et al. (2017) reported net energy values of sweet sorghum silage as 1.59 Mcal kg DM. 


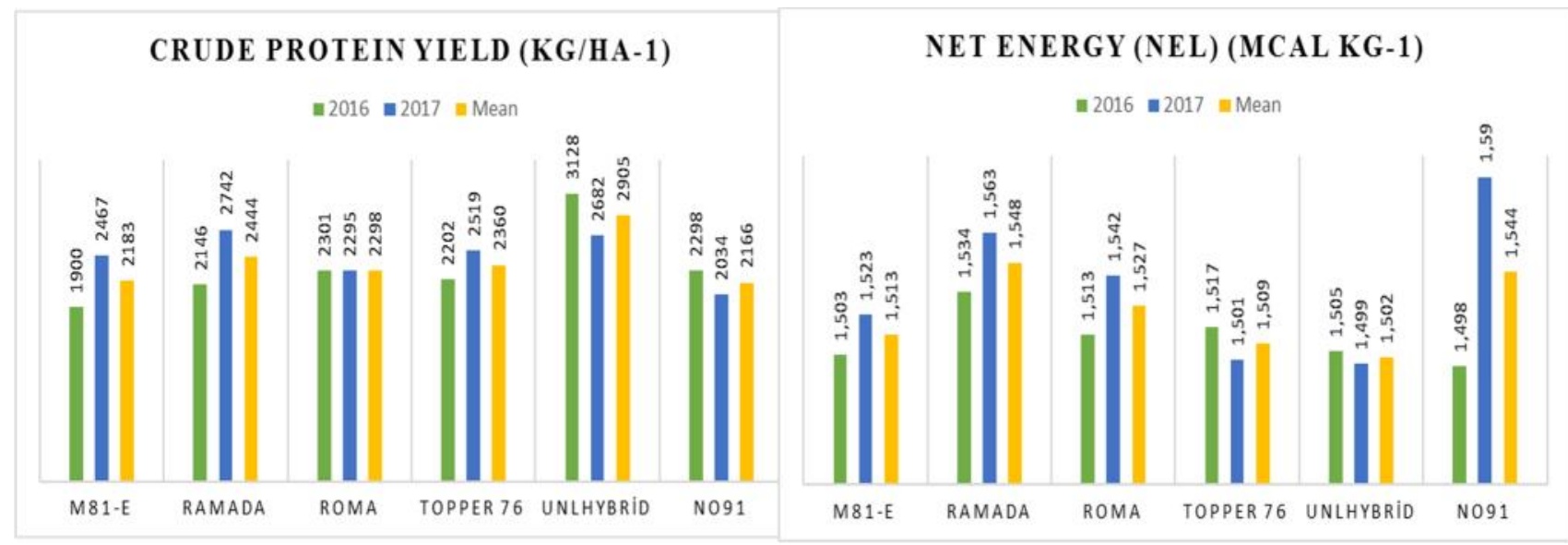

Figure 3. Silage CP yield and NE values of sweet sorghum varieties

Conclusion: Present findings revealed that M81-E, Topper-76, UNL hybrid and No91 varieties were prominent with herbage and DM yield; Ramada and Roma varieties were prominent with silage quality attributes. It was observed in this study conducted at second-crop growing period (June-October) under Eastern Mediterranean (Adana) conditions for 100-120 days that there were sweet sorghum varieties among the investigated plant materials with herbage, dry matter and crude protein yields of above $180 \mathrm{Mg} \mathrm{ha}^{-1}, 50 \mathrm{Mg} \mathrm{ha}^{-1}$ and $2.3 \mathrm{Mg} \mathrm{ha}^{-1}$, respectively. These varieties had RFV of above 150 . Such a value was greater than the RFV of several other feed crops. It was concluded based on present findings that sorghum varieties grown in southern coasts of Turkey had 3-4 times greater yields than maize (Korkmaz et al., 2015; Yücel et al., 2015) and silage quality attributes (NDF, ADF, DMI and RFV) were also better than maize silage. As compared to maize, sorghum is more tolerant to drought and high temperatures, has less fertilizer demands and soil preference. Thus, sorghum can be used as an alternative silage crop to maize and can have great contributions to quality forage supply of the country.

\section{REFERENCES}

Agung, G. A. M. S., K. Sardiana, W. Diara, and G. M. O. Nurjaya (2013). Adaptation, biomass and ethanol yields of sweet sorghum (Sorghum bicolor (L.) Moench) varieties at dryland farming areas of Jimbaran Bali, Indonesia. J. Bio. Agri. Healthcare. 3 (17): 110-115.

Almodares, A., M. R. Hadi, and H. Ahmadpour (2008). Sorghum stem yield and soluble cabohdrates under different salinity levels. Afr. J. Biotechnol. 7 (22): 4051-4055. doi: 10.5897/ajb08.156.

Anonoymous, (2018). SGS Agrifood laboratories. feed/ forages calculations. http:// www.agtest.com/ articles / feed \% 20 and \% 20 forages \% 20 calculations_new.pdf. (Accessed 26.12.2018).
AOAC (Association of Official Analytical Chemists). (1990). Official Method of Analysis, 15th ed. Association of Official Analytical Chemists, Washington, DC. USA, 66-88.

Bellmer, D., R. Huhnke, R. Whiteley, and C. Godsey (2010). The untapped potential of sweet sorghum as a bioenergy feedstock. Biofuels, 1(4): 563-573, https://doi.org/10.4155/bfs.10.34.

Blümmel, M, S. S. Rao, S. Palaniswami, L. Shah, and B. V. S. Reddy (2009). Evaluation of sweet sorghum (Sorghum bicolor (L.) Moench) used for bioethanol production in the context of optimizing whole plant utilization. Anim. Nutr. Feed Techn. 9: 1-10.

Brocke, K. V., G. Trouche, E. Weltzien, C. P. K. Barro, A. Sidibé, and R. Zougmoré (2014). Helping farmers adapt to climate and cropping system change through increased access to sorghum genetic resources adapted to prevalent sorghum cropping systems in burkina faso. Exp. Agric. 50(2): 284305. doi: 10.1017/S0014479713000616.

Cattani, M., N. Guzzo, R. Mantovani, and L. Bailoni (2017). Effects of total replacement of corn silage with sorghum silage on milk yield, composition, and quality. J. Anim. Sci. Biotechno. 8 (15), 1-8. DOI 10.1186/s40104-017-0146-8.

Chakravarthi, M. K., Y. R. Reddy, K. S. Rao, A. Ravi, B. Punyakumari, and B. Ekambaram (2017). A study on nutritive value and chemical composition of sorghum fodder. Int. J. Sci. Environ.. Technol. 6 (1): 104-109.

Contreras-Govea, F. E., M. A. Marsalis, L. M. Lauriault, and B. W. Bean (2010). Forage sorghum nutritive value: A review. Online. Forage Grazinglands, doi:10.1094/FG-2010-0125-01-RV.

Durul, G. (2016). Effect of different cutting times on some quality properties of sweet sorghum (Sorghum bicolor (L.) Moench var. Saccharatum) and bean (Phaseolus vulgaris) silage mixtures. Ege 
University, Institute of Science and Technology, Field Crops Department, M.Sc. Thesis, 72 p (in Turkish).

Ekefre, D. E., A. K. Mahapatra, M. Jr. Latimore, D. D. Bellmer, U. Jena, G. J. Whitehead, and A. L. Williams (2017). Evaluation of three cultivars of sweet sorghum as feedstocks for ethanol production in the Southeast United States. Heliyon, $\quad 3 \quad$ e00490. doi:10.1016/j.heliyon.2017.e00490.

Elseed, A. M. A. F., N. I. N Eldaim, and E. O. Amasaib (2007). Chemical composition and in situ dry matter degradability of stover fractions of five sorghum varieties. J. Appl. Sci. Res. 3(10): 11411145 .

Filya, I. (2003). The effect of Lactobacillus buchneri and Lactobacillus plantarum on the fermentation, aerobic stability, and ruminal degradability of low dry matter corn and sorghum silages. J. Dairy Sci. 86 (11): 3575-3581.

Gnansounou, E., A. Dauriat, and C. E. Wyman (2005). Refining sweet sorghum to ethanol and sugar: economic trade-offs in the context of North China. Bioresour Technol. 96 (9): 985-1002. doi.org/10.1016/j.biortech.2004.09.015

Gomes, S. O., J. B. Pitombeira, J. N. M. Neiva, and M. J. D. Candido (2006). Agronomic behavior and forage composition of sorghum cultivars in the State of Ceará. Rev. Ciênc. Agron. 37 (2): 221227.

Huhtanen, P., H. Khalili, J. I. Nousiainen, M. Rinne, S. Jaakkola, T. Heikkila, and J. Nouisiainen (2002). Prediction on the relative intake potential of grass silage by dairy cows. Livest. Prod. Sci. 73 (2-3): 111-130. doi.org/10.1016/s03016226(01)00279-2.

Iyanar, K., G. Vijayakumar, and A. K. Fazllullah Khan (2010). Correlation and path analysis in multicut fodder sorghum. Electron. J. Plant Breed. 1(4): 1006-1009 (July 2010).

Junior, M. A. P .O., M. Retore, D. M. Manarelli, F. B. de Souza, L. L. M. Ledesma, and A. C. A. Orrico (2015). Forage potential and silage quality of four varieties of saccharine sorghum. Pesq. Agropec. Bras., Brasília. 50(12):1201-1207. DOI: 10.1590/S0100-204X2015001200010.

Kaiser, A. G., J. W. Plitz, H. M. Burns, and N. W. Griffiths (2004). Successful silage. . 2nd ed. Dairy Australia NSW Department of Primary Industries. 468p.

Karthikeyan, B.J., C. Babu, and J.J. Amalraj (2017). Nutritive value and fodder potential of different sorghum (Sorghum bicolor L. Moench) cultivars. Int. J. Curr. Microbiol App. Sci. 6 (8): 898-911. https://doi.org/10.20546/ijcmas.2017.608.112
Korkmaz, Y., S. Aykanat, H. Yucel, M. Avci, C. Yucel, ve R. Hatipoglu (2015). A research on yield and silage quality of silage corn (Zea mays L.) cultivars as second crop in Cukurova Condition. TAGEM (Agricultural Research and Policy General Directorate) Final Project Report (in Turkish with abstract English).

Korpos, M. G., J. Feczak, and K. Reczey (2008). Sweet sorghum juice and bagasse as a possible feedstock for bioethanol production. Hungar. J. Ind. Chem. $36(1-2): 43-48$.

Kumar, T. V. A., D. V. K. Samuel, S. K. Jha, and J. P. Sinha (2015). Twin screw extrusion of sorghum and soya blends: a response surface analysis. J. Agr. Sci. Tech. 17: 649-662.

Lema, M., A. Felix, S. Salako, and U. Bishnoi, (2001). Nutrient content and in vitro dry matter digestibility of silages made from various sweet sorghum cultivars. J. Appl. Anim. Res. 20(1): 99106, DOI: 10.1080/09712119.2001.9706742.

Littell, R. C., G. A. Milliken, W. W. Stroup, R. D. Wolfinger, and O. Schabenberger (2006). SAS for Mixed Models. Second Edition, Cary, NC, SAS Institute Inc.

Madibela, O. R., W. S. Boitumelo, C. Manthe, and I. Raditedu (2002). Chemical composition and in vitro dry matter digestibility of local landraces of sweet sorghum in Botswana. Livestock Res. Rural. Dev. 14(4): http://www.lrrd.org/lrrd14/4/madi144.htm.

Mahmood, A., H. Ullah, M. Ijaz, M. M. Javaid, A. N. Shahzad, and B. Honermeier (2013). Evaluation of sorghum hybrids for biomass and biogas production. Aust. J. Crop Sci. 7 (10): 1456-1462.

Mastrorilli, M,, N. Katerji, and G. Rana (1999). Productivity and water use efficiency of sweet sorghum as affected by soil water deficit occurring at different vegetative growth stages. Eur. J. Agron. 11: 207-215.

Monti, A., N. diVirgilio, and G. Venturi (2008). Minerals composition and ash content of six major energy crops. Biomass Bioenerg. 32 (3): 216-223. https://doi.org/10.1016/j.biombioe.2007.09.012.

Neto, A. B., R. H. P. dos Reis, L. Da.S. Cabral, J. G. de Abreu, D. de. P. Sousa, and F. G. de Sousa (2017). Nutritional value of sorghum silage of different purposes. Ciênc. Agrotec. 41(3): 288299. http://dx.doi.org/10.1590/141370542017413038516.

Perazzo, A. F., G. G. P. Carvalho, E. M. Santos, H. F. C. Bezerra, T. C. Silva, G. A. Pereira, R. C. S. Ramos, and J. A. S. Rodrigues (2017). Agronomic evaluation of sorghum hybrids for silage production cultivated in semiarid 
conditions. Front. Plant Sci. 8: 1088. 1-8. doi: 10.3389/fpls.2017.01088

Poehlman, J. M. (1994). Breeding sorghum and millet. In Breeding field crops, 3rd ed, ed. J.M. Poehlman, 508-541. Ames, Iowa, USA: Iowa State University Press.

Reddy, G. V. N., A. R. Reddy, Y. Anjaneyulu, and Y. R. Reddy (2005). Technologies for enhancing feed quality, publication of results of team of excellance on feed technology and quality assurance (NATP). Angrau, Hyderabad, India.

Reise, F. and A. Almodares (2008). The effect of planting date on amylose content in sorghum and corn. In: Proceeding of the 3rd Int. Biol. conference (Eds. F Reisi \& A Almodares). Tehran, Iran.

Rodrigues, F. O., A. F. de S. França, R. de P. Oliveira, E. R. de Oliveria, B. Rosa, T. V. Soares, and S. Q. S. Mello (2006). Produção e composição bromatológica de quatro híbridos de sorgo forrageiro (Sorghum bicolor (L.) Moench) submetidos atrês doses de nitrogênio. Ciênci. Anim. Bras. 7 (1): 37-48.

Sankarapandian, R., S. Audilakshmi, V. Sharma, K. Ganesamurthy, H. S. Talwar, and J. V. Patil (2013). Effect of morpho-physiological traits on grain yield of sorghum grown under stress at different growth stages, and stability analysis. J. Agric. Sci. $151 \quad$ (5): 630-647. doi.org/10.1017/S002185961200072X.

Santos, E. M., T. C. da Silva, C. H. O. Macedo and, F. S. Campos (2013). Lactic acid bacteria in tropical grass silages. Lactic acid bacteria: R \&D for Food, Health and Livestock Purposes, M. Kongo. (Ed). InTech Publisher, Rijeka:Croatia, 335-362. http://www.doi.org/10.5772/2825.
Schroeder. J. W. (1994). Interpreting forage analysis. Extention Dairy Specialist (NDSU). AS-1080, North Dakota State University.

Tesso, T. T., L. E. Claflin, and M. R. Tuinstra (2005). Analysis of stalk rot resistance and genetic diversity among drought tolerant sorghum genotypes. Crop Sci. 45 (2): 645-652. doi:10.2135/cropsci2005.0645.

Trulea, A., T. Vintila, G. Pop, R. Sumalan and, S. Gaspar (2013). Ensiling sweet sorghum and maize stalks as feedstock for renewable energy production. Res. J. Agri. Sci. 45 (3): 193-199.

Turgut, I., U. Bilgili, A. Duman, and E. Acikgoz (2005). Production of sweet sorghum (Sorghum bicolor L. Moench) increases with increased plant densities and nitrogen fertilizer levels. Acta Agr. Scand. BS-P.S. 55 (3): 236-240.

Van Soest, P. J., J. D. Robertson, and B. A. Lewis (1991). Methods for dietary fiber, and nonstarch polysaccharides in relation to animal nutrition. $\mathrm{J}$. Dairy Sci. 74: 3583-3597.

Yucel, C., M. Avci, I. Inal, M. R. Akkaya (2015). Effects of different mixing ratios and cutting time of some annual legume and cereal forage crops on silage quality in Cukurova conditions. TAGEM (Agricultural Research and Policy General Directorate ) Final Project Report (in Turkish with abstract English).

Yucel, C., R. Hatipoglu, I. Dweikat, I. Inal, F. Gündel, and H. Yucel (2018). A Research on determination of biyo-etanol production potential of different sweet sorghum (Sorghum bicolor var. saccharatum (L.) Mohlenbr.) Genotypes in Çukurova and GAP regions. TUBITAK 1003 Project Final Report (Abstract in English), p.293. 